\title{
ŠV. POPIEŽIAUS JONO PAULIAUS II PASKELBTU PASAULINĖS LIGONIŲ DIENOS MINĖJIMO VIETŲ MARIJIŠKUMAS
}

\author{
Remigijus Oželis \\ Klaipèdos universitetas
}

\begin{abstract}
Anotacija
Moderniame technologizuotame XXI amžiuje žmogus, apsuptas tobulëjančios medicinos ir gerejjančiu gyvenimo sąlygu, suklumpa ties liga ir jos sukelta kančia. Šiame ligu ir skausmo kupiname pasaulyje Bažnyčia ịvairiais sielovados būdais parodo savo rūpesti ligoniais. Šventasis popiežius Jonas Paulius II 1992 m. oficialiai ¡vedè kasmetini Pasaulinès ligoniu dienos minejjima vasario 11 diena, kai Kataliku Bažnyčia švenčia Lurdo Švč. Mergelès Marijos liturgini minejjima. 1993 m. vasario 11 d. pirma karta paminèta Pasauline ligoniu diena. Jonas Paulius II paskelbè trylika Pasaulinių ligoniụ dienu (1993-2005) ir joms parašé laiškus-žinias. Be to, jis j̣vede tradicija kasmet Pasauline ligonių dieną švęsti svarbioje pasirinktos šalies šventoveje, kuri dedikuota Švč. Mergelei Marijai. Jai skirtu šventoviu pasirinkimas atskleidžia, kad Bažnyčia dèmesingai užjaučia visus kenčiančiuosius fiziškai ir dvasiškai, tikint Švč. Mergelès Marijos užtarimu kreipiamasi $i$ Viešpati, prašant sveikatos ligoniams, o ligoniais besirūpinantiems Jèzaus Motina Marija parodoma kaip tobulos Dievo ir artimo meiles pavyzdys. Straipsnyje apžvelgiamos Jono Pauliaus II laiškuose nurodytos Ligonių dienos minejimo vietos, susijusios su Švč. Mergele Marija. Aptariant Pasaulinès ligonių dienos šventimo vietu marijiškuma, atsiskleidžia šventojo popiežiaus rūpestis ligoniais ir tais, kurie atlieka jiems meilès tarnystę. PAGRINDINIAI ŽODŽIAI: šventasis popiežius Jonas Paulius II, Švč. Mergele Marija, Pasaulinè ligonių diena, Bažnyčia.
\end{abstract}

\begin{abstract}
In the modern technologized XXI century, the man, surrounded by advancing medicine and improving conditions of life, stumbles upon the disease and the suffering it causes. In such a world full of disease and pain, the Church shows care for the sick in various spiritual ways. On February 11, 1992 St Pope John Paul II officially introduced the annual commemoration of the World Day of the Sick, when the Catholic Church celebrates the liturgy of Our Lady of Lourdes. The World Day of the Sick was first commemorated on 11 February, 1993. John Paul II pronounced thirteen world days of the sick (1993-2005) and addressed them with special lettersmessages. Also, John Paul II introduced the tradition of celebrating the World Day of the Sick every year in an important shrine dedicated to the Blessed Virgin Mary of a chosen country. The choice of such shrines dedicated to Mary reveals that the
\end{abstract}


Church is attentive to all suffering physically and spiritually, that the intercession of the Blessed Virgin Mary is called upon in the prayers for health for the sick, and the Mother Mary of Jesus is shown to those caring for the sick as an example of the perfect love of God and neighbour. This article reviews the places of commemoration of the day of the sick associated with the Blessed Virgin Mary in the letters of Pope John Paul II. Discussing the marianism of the places of commemoration of the world days of the sick, the care of Pope John Paul II for the sick and those who perform the service of love for the sick is revealed.

KEY WORDS: Saint Pope John Paul II, The Blessed Virgin Mary, the World Day of the Sick, Church.

DOI: http://dx.doi.org/10.15181/mtd.v0i6.2200

\section{İžanga}

Krikščioniško tikejjimo centras yra Jėzaus, iš moters gimusio Dievo Sūnaus, išpažinimas. Jėzų pagimdžiusi Mergelė Marija yra „malonėmis apdovanotoji“ (Lk 1, 28). Moteris krikščionių tikejjime tampa vilties ženklu, artinančiu prie Dievo. Pamaldumas Dievo Motinai Marijai yra kristocentriškas, giliausiai įsišaknijęs Triasmenèje Dievo paslaptyje, susijęs su İsikūnijimo ir Atpirkimo paslaptimis. Marija tampa naujaja Ieva, kurią Dievas stato šalia naujojo AdomoKristaus, pradedant nuo apreiškimo, per gimimą Betliejuje, vestuves Galilejos Kanoje iki Golgotos kryžiaus ir Sekminių vakarienės. Jėzus, Dievo Sūnus, Dievo atspindys, per kurị visa sukurta, susijungė su žeme igydamas žmogišką pavidalą Mergelès Marijos įsčiose. Tad Atpirkèjo Jèzaus Kristaus Motina yra ir Bažnyčios Motina, ị kurią su pasitikèjimu kreipiamasi užtarimo.

Šv. popiežius Jonas Paulius II ypatingą dėmesị skyrè Švč. Mergelès Marijos vaidmeniui kreipiant Jėzaus Kristaus link. Šventasis Tẻvas nurodo, kad ịsiklausę i tai, ką sako Švenčiausioji Mergelè Marija, galime „gyvai ir jaudinančiai iš naujo ịžvelgti jos misiją Kristaus ir Bažnyčios slèpinyje: misiją, kuri ima ryškèti jau Evangelijoje, kai Marija prašo Jėzaus padaryti pirmajị stebuklą ir per vestuves Galilejos Kanoje tarnams sako: „Darykite, ką tik jis jums lieps“ (Jn 2, 5). Fatimoje ji pakartoja aiškius Sūnaus žodžius, pasakytus jo veiklos pradžioje: ,Atėjo metas ir prisiartino Dievo karalystė: „Atsiverskite ir tikèkite Evangelija!“” (Mk 1, 15). Primygtinis Marijos rei- 
kalavimas atgailauti išreiškia ne ką kita, kaip tik jos motinišką susirūpinimą žmonių šeimos likimu, žmonijos, kuriai reikia atsivertimo ir atleidimo“ (Popiežius Jonas Paulius II, 1997, nr. 1). Marija rūpinasi žmonija, rodydama kryptị sunkiame gyvenimo kelyje, ji nesiliauja kartojusi žodžių: „Darykite, ką tik jis jums lieps!“ (Jn 2, 5). Ji kviečia daryti, ką Jėzus liepia, kviečia gyventi Jėzaus Geraja naujiena.

(Lot.) „Totus Tuus, Maria“ („Visas Tavo, Marija“) - tai šv. popiežiaus Jono Pauliaus II pasirinktas pontifikato moto. Šis moto Šventajam Tẻvui nebuvo tik pagarbaus pobūdžio ar tik pasiaukojimo išraiška. Kai svarste apie Švenčiausiają Mergelę Mariją, kalbejjo ne tik apie tam tikrą jausminị polinkį, bet ir apie objektyvią tiesą, susijusią su Dievo Gimdytoja (Jonas Paulius II, 1995, p. 165). Neatsitiktinai įsteigdamas kasmetinị Pasaulinị ligonių dienos minëjimą, šv. Jonas Paulius II ji susiejo su Dievo Motina Marija. Nuo pat Pasaulinès ligonių dienos ịsteigimo kasmet popiežius skelbe „Laišką / Žinią Pasaulinès ligonių dienos proga“. Šv. Jonas Paulius II jų, skirtų Pasaulinei ligonių dienai 19932005 metais, paskelbẻ trylika. Tai reikšmingi Katalikų Bažnyčios dokumentai, kurie gali būti teologinių, socialinių, sveikatos ir kitų mokslų tyrinėjimų šaltinis. Deja, lietuviškoje erdvejje popiežių žinios Pasaulinès ligonių dienos proga moksliškai neanalizuotos. Išimtis - doc. dr. Sauliaus Stumbros publikacija apie popiežiaus Pranciškaus laiškus Pasaulinès ligonių dienos proga, kur aptarti šeši popiežiaus Pranciškaus laiškai (žr. Stumbra, 2019, p. 111-126).

Šiame straipsnyje aptariamas Švenčiausiosios Mergelès Marijos vaidmens išskirtinumas Jono Pauliaus II laiškuose I-XIII Pasaulinės ligonių dienos proga.

Tyrimo o bj e k ta s : šv. popiežiaus Jono Pauliaus II paskelbtų Pasaulinès ligonių dienos šventimo vietų marijiškumas.

Straipsnio tiks las: apžvelgti šv. popiežiaus Jono Pauliaus II paskelbtų Pasaulinès ligonių dienos minẻjimo vietų marijiškumą.

Me todai : oficialių Bažnyčios dokumentų sisteminio tyrimo, analizès, interpretavimo ir apibendrinimo.

Kadangi tiriama Švč. Mergelès Marijos vaidmens raiška šv. popiežiaus Jono Pauliaus II žiniose Pasaulinès ligonių dienos proga, tyrime pirmiausia remiamasi Jono Pauliaus II raštais. 


\section{Pasaulinės ligonių dienos paskelbimas}

Šv. popiežius Jonas Paulius II 1992 m. gegužès 13 d. oficialiai ịsteige kasmetinį Pasaulinès ligonių dienos minejjimą vasario 11 dieną, kai Katalikų Bažnyčia švenčia Lurdo Švč. Mergelès Marijos liturginį minèjimą (Visuotinis Romos kalendorius, 2020). Kitais metais, t. y. 1993 m. vasario 11 d., pirmą kartą paminèta Pasaulinè ligonių diena, tam pasirinkta Lurdo (Prancūzijoje) šventovè (Popiežius Jonas Paulius II, 2002, nr. 1), kuri nuo Švč. Mergelès Marijos apsireiškimo Lurde XIX a. pabaigoje garsèja stebuklingais ligonių pasveikimais. Pažymint tai, kad Bažnyčia visada daug dėmesio skiria ligoniams ir kenčiantiesiems visame pasaulyje, Pasaulinès ligonių dienos minèjimu Šventasis Tẻvas siekè parodyti išskirtini dėmesị kenčiantiesiems fiziškai ir dvasiškai, pavesdamas juos Dievo Motinos globai, taip pat tiems, kurie padeda ligoniams, nurodydamas Jèzaus Motiną Mariją kaip tobulos Dievo ir artimo meilès pavyzdị (Popiežius Jonas Paulius II, 1999, nr. 2).

Prie Pasaulinès ligonių dienos paskelbimo artėta nuosekliai. 1985 m. vasario 11 d. Jonas Paulius II, siekdamas ypatingą dèmesį atkreipti ị ligonių sielovadą, apaštaliniu laišku Motu proprio „Dolentium hominum“ įsteigè Popiežiškają komisiją (John Paul II, 1985), kuri vẻliau tapo Popiežiškaja taryba, kurios siekis - sveikatos priežiūros darbuotojų pastoracinè pagalba tiems, kurie tarnauja ligoniams ir kenčiantiesiems, kad gailestingumo apaštalavimas, kuri jie vykdo, veiksmingai patenkintų visų poreikius (Message of the Holy Father Pope John Paul II for the III World Day of the Sick [1995], 1994, nr. 2; Makhalemele, 2020). Tiek Popiežiškosios komisijos ịsteigimas, tiek ir Pasaulinès ligonių dienos šventimas susijęs su vasario 11-ąja - Lurdo Švč. Mergelès Marijos minejjimo diena. Kalbėdamas apie ligonius ir Dievo Motiną Mariją Jonas Paulius II sako, kad Bažnyčia verčia savo reikšmingiausius istorijos puslapius, rūpindamasi ligoniais ir kenčiančiaisiais palaikoma, guodžiama Švenčiausiosios Mergelès Marijos užtarimu (Message of the Holy Father Pope John Paul II for the IV World Day of the Sick [1996], 1995, nr. 4). Popiežius Jėzų Kristų, Dievo Sūnų, mato per Mergelę Mariją, todèl ir ị ligonius kreipiasi kaip ị tuos, kurie turi malonę tikẻdami ị Jèzų Kristų, gyvojo Dievo Sūnų, kuris tapo žmogumi Mergelès Marijos ịsčiose (Message of the Holy Father Pope John Paul II for the II World Day of the Sick [1994], 1993, nr. 1). 
Pasaulinès ligonių dienos minèjimą Jonas Paulius II paskelbè, kad visi tikintieji skirtų tam ypatingą maldos ir bendradarbiavimo laiką, kančią ịprasmindami Bažnyčios labui, kad kiekvienas savo sergančiame brolyje ar seseryje išvystų Kristaus veidą, kuris kančios, mirties ir prisikèlimo dẻka suteikè žmonijai išgelbejimą (Message of the Holy Father Pope John Paul II for the First Annual World Day of the Sick [1993], 1992, nr. 1). Jonas Paulius II pažymi, kad Marijos, Ligonių sveikatos, akivaizdoje kreipiasi ị tuos, kurie fiziškai ir dvasiškai neša žmonių kančios ženklus, ir ị tuos, kurie tarnaudami sergantiesiems ir kenčiantiesiems seka Atpirkejją Jèzų Kristų (Message of the Holy Father Pope John Paul II for the IV World Day of the Sick [1996], 1995, nr. 1).

Šventasis Tèvas Jonas Paulius II, skelbdamas kasmetinị Pasaulinės ligonių dienos šventimą, numato ir šios dienos uždavinius: padèti Dievo tautai, kartu daugeliui katalikų sveikatos priežiūros ịstaigų ir pačiai visuomenei geriau suvokti būtinybę užtikrinti geriausią ligonių priežiūrą; sergančiam asmeniui išgyventi kančią žmogiškuoju lygmeniu, bet visų pirma antgamtiniu; vyskupijoms, krikščionių bendruomenèms ir šeimoms dalyvauti sveikatos rūpybos apaštalavimo darbe; skatinti vis labiau vertinamą savanorių įsipareigojimą; priminti žmonėms dvasinio ir moralinio sveikatos priežiūros darbuotojų mokymo svarbą; padèti tiek ligoniams, tiek ir juos prižiūrintiesiems geriau suvokti maldos svarbą vykdant ligonių sielovadą (Message of the Holy Father Pope John Paul II for the First Annual World Day of the Sick [1993], 1992, nr. 1-5; Stumbra, 2019, p. 111). Visuotinès Bažnyčios nariai kviečiami tarnystès dvasia švęsti Pasaulinę ligonių dieną, kaip ypatingą dvasinio ir socialinio augimo progą, išskirtinai ịsiklausant, apmąstant ir veiksmingai atsiduodant ligoniams. Mininčiuosius šią dieną popiežius paveda Švenčiausiosios Mergelès Marijos globai. Ligonių dienų marijiškumas „teikia progą ịsiklausyti ị Mergelès Marijos naujieną, kuri, kaip ir Evangelija, iš esmès kviečia atsiversti ir atgailauti““ (Popiežius Jonas Paulius II, 1997, nr. 1).

\section{Pasaulinės ligonių dienos šventimo vietų marijiškumas}

Šventasis popiežius Jonas Paulius II paskelbdamas Pasaulinę ligonių dieną numatẻ kasmet vasario 11 dieną ją minèti skirtingose pasaulio vietose, 
kurios susijusios su Švenčiausiosios Mergelès Marijos šventovemis. Tokios vietos, dedikuotos Švenčiausiajai Mergelei Marijai, teikia ramybę sergantiesiems ir stiprybę jiems padedantiesiems. Ligoniai su pasitikejjimu kreipiasi i Dievo Motiną prašydami užtarimo ir globos. Ramybė, kurią gali suteikti dieviškasis Gydytojas Jèzus Kristus Motinai Marijai užtariant, pritraukia kenčiančiuosius ị Dievo Motinai Marijai skirtas šventoves (Makhalemele, 2020). Apie tai, kad Marijos garbei skirtose vietose ligoniai atranda ramybę, rašo pats popiežius: „Kartais tai būna kūno ramybė, kai Dievas savo Apvaizda išgydo ligą; tačiau dažniau tai būna dvasios ramybè, kai siela, persmelkta malonès vidinès šviesos, randa jègų priimti skausmingą ligos naštą ir per bendrystę su Kristumi, kenčiančiuoju Dievo tarnu, paversti ją savo ir kitų išganymo ịrankiu““ (Popiežius Jonas Paulius II, 1997, nr. 2).

\subsection{Pasaulinès ligonių dienos $1993 \mathrm{~m}$. vasario $11 \mathrm{~d}$. minẻjimo vieta - Lurdo (Prancūzija) Švč. Mergelès Marijos Nekaltojo Prasidèjimo šventovè}

Ivvesdamas tradiciją kasmet vasario 11 d. švęsti Pasaulinę ligonių dieną popiežius Jonas Paulius II pasirinko Lurdo Dievo Motinos minèjimo dieną vasario 11 d. (Message of the Holy Father Pope John Paul II for the First Annual World Day of the Sick [1993], 1992, nr. 1). Tad ir I Pasaulinès ligoniu dienos minejjimo vieta pasirinktas Lurdas, miestas Prancūzijos pietvakariuose, kur 1858 m. Bernadetai Subiru apsireiškè Nekaltai Pradètoji Švenčiausioji Mergelè Marija.

Pietų Prancūzijoje, Pirènų kalnų slènyje, įsikūrusị Lurdo miestą galima vadinti pasaulio piligrimų sostine, nes čia kasmet apsilanko beveik 6 milijonai piligrimų iš viso pasaulio. Ta vietovè susijusi su Švč. Mergelès Marijos apsireiškimais Bernadetai Subiru. Pirmasis Švč. Mergelès Marijos apsireiškimas ịvyko $1858 \mathrm{~m}$. vasario $11 \mathrm{~d}$., paskutinis - tų pačių metų liepos $16 \mathrm{~d}$. Minètų metų vasario 11 dieną Subiru šeimos namuose neliko malkų, tad Bernadeta su sesute Antuanete ir drauge Žana Abadi išejo pasirinkti sausų šakų. Mergaitès prièjo Masabielio kalno urvą, kurio gilumoje Bernadeta pamatė akiai mielą Šviesą, kurioje išryškejjo šypsena ir pasirode jauna moteris, 
vilkinti baltais drabužiais. Regètoji moteris buvo basa, jos pėdas puošè po auksaspalvę rožę, rankose laikė rožinį. Per kitus apsireiškimus Bernadeta klausè Apsireiškusiosios, kas tokia esanti. 1858 m. kovo 25 d. sudejusi rankas ir pakèlusi akis ị dangų Apsireiškusioji atsakiusi: „Aš esu Nekaltasis Prasidejjimas.“ Apsireiškimų vietoje pastatyta šventovè, primenanti Marijos kvietimą garbinti Jèzų Kristų (Lileikienè, 2007, p. 186-189).

Skelbdamas Žinią I Pasaulinès ligonių dienos proga (Message of the Holy Father Pope John Paul II for the First Annual World Day of the Sick [1993], 1992), jos pradžioje (nr. 1) popiežius nurodé, kad Pasaulinè ligonių diena bus švenčiama per Marijos, Lurdo Dievo Motinos, minèjimą, o žinios pabaigoje (nr. 6) ligonius pavedè Marijos globai ir užtarimui, nurodydamas, kad palaimintoji Mergelé, Ligonių Sveikata bei Gyvenimo Motina, yra mūsų parama ir viltis. Minint Lurdo Dievo Motiną, kurios šventykla Pirènu papėdejje tapo žmonių kančių šventove, artejjama prie kryžiaus kančios taip, kaip Marija tai atliko Kalvarijoje, Sūnaus kryžiaus papėdejje. Šią dieną, prašant Marijos užtarimo, i ją kreipiamasi kaip ị Lurdo Dievo Motina.

\subsection{Pasaulinès ligonių dienos $1994 \mathrm{~m}$. vasario $11 \mathrm{~d}$. minèjimo vieta - Čenstakavos (Lenkija) Dievo Motinos šventovè}

Popiežius Jonas Paulius II, būdamas lenkas, II Pasaulinei ligonių dienai minèti pasirinko savo tèvynès šventovę Lenkijos pietuose, skirtą Dievo Motinai Marijai (Message of the Holy Father Pope John Paul II for the II World Day of the Sick [1994], 1993, nr. 1). Jasna Guros vienuolynas ir bažnyčia Čenstakavoje yra visame pasaulyje garsi piligrimystès vieta. Šioje Lenkijoje svarbiausioje Švenčiausiosios Mergelès Marijos šventoveje pagerbiamas Čenstakavos Švenčiausiosios Dievo Motinos paveikslas, ịvardijamas ịvairiais jo maloningumą atskleidžiančiais pavadinimais.

Pasak legendos, garsusis Čenstakavos paveikslas, nutapytas šventojo evangelisto Luko, saugotas netoli Jeruzalès, vèliau - Konstantinopolyje, dar vèliau - Rusijoje. Galų gale jis atiteko Opolès kunigaikščiui Vladislavui, kuris, remdamasis dangiškaisiais ženklais, šį Marijos atvaizdą $1382 \mathrm{~m}$. padovanojo Jasna Guros Švenčiausiosios Mergelès Marijos Ėmimo ị dangų bažny- 
čiai ir pavedè ji globoti paulinams, kuriems toje vietoje pastatė vienuolyną su bažnyčia (Stankevičienè, 2004, p. 61). Šiandien Čenstakavos Švenčiausioji Mergelè Marija laikoma Lenkijos kančių ir tvirtybès simboliu, nacionaliniu Lenkijos simboliu.

Skelbdamas Žinią II Pasaulinès ligonių dienos proga (Message of the Holy Father Pope John Paul II for the II World Day of the Sick [1994], 1993) Jonas Paulius II jos pradžioje (nr. 1) nurodè oficialią Ligonių dienos šventimo šventovę Čenstakavoje, dedikuotą Švenčiausiajai Mergelei Marijai. Laiške, tiesiogiai Marijos vardo neminėdamas, jis pabrèžè, kad tik per [Marijoje] İsikūnijusį Žodị atrandame atsakymą ị klausimą, kodèl kančia egzistuoja (nr. 3); kalbejjo apie Jėzaus kančią ant kryžiaus (nr. 5), vėlgi tiesiogiai Marijos neįvardydamas, bet galima daryti prielaidą, kad popiežius mintyje turejjo ir Marijos buvimą prie kryžiaus; kenčiantiesiems Mariją pristate kaip pavyzdị, kaip išgyventi kančią (nr. 6). Pabaigos palaiminime (nr. 9) Šventasis Tẻvas kreipèsi ị Mariją, Ligonių Sveikatą. Šiame laiške Marija ịvardijama kaip Lurdo Mergele, Palaimintoji Mergelè, Motina, Ligoniu Sveikata, Gyvoji Evangelijos Ikona, Kančios Evangelijos Ikona.

\subsection{Pasaulinès ligonių dienos $1995 \mathrm{~m}$. vasario $11 \mathrm{~d}$. minèjimo vieta - Jamusukro (Dramblio Kaulo Krantas) Marijos Taikos Karalienès bazilika}

1995 m. svarbiausias minèjimas, susijęs su Pasauline ligonių diena, vyko Afrikos žemėje, Dramblio Kaulo Krante. Tai buvo bažnytinis susirinkimas, dvasiškai susijęs su Vyskupų sinodo specialiąja Afrikos asamblèja; kartu tai buvo puiki proga tikejjimą paliudyti Dramblio Kaulo Kranto bažnyčiai, mininčiai pirmujų misionierių atvykimo šimtmetị (Message of the Holy Father Pope John Paul II for the III World Day of the Sick [1995], 1994, nr. 2).

Jamusukro, esančio šalies vidurinèje dalyje, Švenčiausiosios Dievo Motinos Taikos Karalienès bazilika yra didžiausia visame pasaulyje krikščionių bažnyčia. 1983 m. Dramblio Kaulo Kranto sostinė perkelta ị Jamusukrą. Tada ir kilo mintis naujoje sostinejje pastatyti naują bažnyčią. Jos statymas ir finansavimas inicijuotas pirmojo Dramblio Kaulo Kranto prezidento Fe- 
lix’o Houphouet-Boigny. Šventovė suprojektuota pagal Šv. Petro bazilikos Vatikane pavyzdị. 1985 m. rugpjūčio 10 d. popiežius Jonas Paulius II atvykęs i Jamusukrą pašventino bazilikos kertinį akmenį. Šventovè baigta statyti ir konsekruota 1990 m. Tad piligrimyste i Jamusukro Švenčiausiosios Dievo Motinos Taikos Karalienès baziliką, kuri yra ne tik pati didžiausia, bet ir aukščiausia visame pasaulyje krikščionių šventovè, - gana naujas reiškinys (Melton, 2010, p. 306-307; Yamoussoukro Basilica, 2020).

Skelbdamas Žinią III Pasaulinès ligonių dienos proga (Message of the Holy Father Pope John Paul II for the III World Day of the Sick [1995], 1994) popiežius Jonas Paulius II nurode Jamusukro Švenčiausiosios Mergelès Marijos šventovę (nr. 2). Laiške popiežius sergančiųjų auką Marijai tarpininkaujant susiejo su Jėzaus Kristaus atpirkimo auka (nr. 5). Žinios pabaigoje (nr. 6) ligonius ir jiems tarnaujančiuosius pavedè Marijos, Kenčiančiujų Motinos, globai, meldžiant, kad Kenčiančiųjų Motina būtų šalia tų, kurie patiria išbandymus, ir palaikytų tuos, kurie savo gyvenimą skiria tarnauti ligoniams. Šiame laiške Marija įvardijama kaip Taikos Karaliene, Sielvartingoji Motina, Kenčiančiujų Motina.

\subsection{Pasaulinès ligonių dienos $1996 \mathrm{~m}$. vasario $11 \mathrm{~d}$. minèjimo vieta - Gvadalupès (Meksika) Dievo Motinos bazilika}

Meksikos tautos Bažnyčia minejjo stebuklingo Gvadalupès Dievo Motinos paveikslo vainikavimo šimtmetị, tad iškilmingiausia Pasaulinès ligonių dienos minejjimo vieta pasirinkta Meksikos šventovė Gvadalupėje (Message of the Holy Father Pope John Paul II for the IV World Day of the Sick [1996], 1995, nr. 1). Gvadalupe - ispaniškas vardas, taip vadinta Ispanijoje tekanti upè. Šis žodis turbūt kilo iš arabų kalbos ir reiškia „upės vaga“, „upès kanalas". Iš tiesų Marijos vaidmenį išganymo plane galètume palyginti su upès vaga, kuri nukreipia gyvajị vandenį - Dievo malonę - žmonių link, o žmones veda pas savo Sūnų - Gyvojo vandens šaltinị. Vis dèlto kai kurie tyrinètojai mano, kad Mergelè Marija, apsireiškusi indènui Jonui Didakui, galèjo vartoti Nahuatlių kalbos žodị coatlaxopeuh, kuris tariamas [quatlasupe], panašiai kaip Gvadalupè, ir reiškia: „Toji, kuri sutraiško gyvatę“ (Jurkštas, 2014). 
1531 m. Švenčiausioji Mergelè Marija, apsireiškusi Tepeyaco kalno papėdejje, kuri šiandien vadinama Gvadalupe, regètojui Jonui Didakui tarè: „Aš esu Švenčiausioji Mergele Marija, vienintelio tikrojo Dievo Motina (...). Didžiai trokštu, kad šioje vietoje man būtų pastatyta bažnyčia, kurioje galèčiau skleisti savo meilę, atjautą ir pagalbą. Čia skirsiu žmonèms visą savo meilę, gailestingumą, pagalbą, paguodą, išganymą. Aš esu užjaučiančioji Motina: tavo ir visų šiame krašte gyvenančių žmonių Motina, taip pat Motina visų kitų tautų, kurios mane myli ir manęs šaukiasi. Esu Motina visų manęs ieškančių ir manyje viltị randančių. Čia išklausysiu visas jūsų raudas ir skundus, guosiu jus liūdinčius ir švelninsiu jūsų kančias, vaduosiu iš visų sielvartų, skurdo ir kentejjimų. (...) labai trokštu tureti čia savo buveinę“ (Badde, 2008, p. 24). Tuo metu sunkiai sirgo regetojo Jono Didako dèdè. Kuklus indènas Jonas Didakas iš Dangaus Karalienès išgirsta guodžiančius ir ramybę teikiančius žodžius: „Tegu niekas tavęs nebaugina! Tegu niekas neliūdina ir neatima vilties! Nebijok nei tos, nei jokios kitos ligos, nebijok ir nenusimink. Argi nesu prie tavęs aš - tavo Motina? Ar negloboju tavęs ir tavimi nesirūpinu? Argi nesu tavo džiaugsmo versmè? Argi mano apsiausto klostès neteikia tau prieglobsčio? Ar nelaikau tavęs savo glèby? Tai ko tau dar trūksta? Tegu niekas tavęs nebaugina ir neatima pasitikejjimo! Taip pat tegu tavęs nekamuoja dẻdès liga. Jis nemirs. Patikèk, jis jau pasveiko!“ (Badde, 2008, p. 31; Message of the Holy Father Pope John Paul II for the IV World Day of the Sick [1996], 1995, nr. 1).

Visa Žinia IV Pasaulinès ligonių dienos proga (Message of the Holy Father Pope John Paul II for the IV World Day of the Sick [1996], 1995) persunkta marijiškumo. Pirmiausia (nr. 1) Jonas Paulius II paaiškino, kodèl pasirinko Gvadalupę, Mariją vadindamas Gvadalupės Dievo Motina ir pažymėdamas, kad jis ị ligonius kreipiasi Marijos, Ligonių Sveikatos, akivaizdoje. Jėzaus Motiną pristatè (nr. 2) kaip pavyzdi ir vadovę tiek ligoniams, tiek ir juos globojantiesiems. Ypač akcentavo (nr. 3), kad ji yra evangelizacijos pavyzdys. Laiško viduryje pabrezžè (nr. 4), kad Marija guodžia ir užtaria Bažnyčią, o sergančiuosius kviečia (nr. 6) savo skausmą išgyventi puoselèjant bendrystę su Jėzumi Kristumi ir Švelniausiaja Motina. Pabaigoje (nr. 8) Jonas Paulius II visus kenčiančiuosius ir jiems padedančiuosius pavedè Marijos globai, melsdamas, kad Jėzaus Motina, per amžius garbinama garsiojoje Gvadalupės Die- 
vo Motinos šventovèje, išgirstų kenčiančiųjų verksmą, nusausintų skausmo ašaras ir būtų šalia visų pasaulio ligonių. Šiame ypač marijiniškame laiške pateikiama daugybė kreipinių i Mariją: Švenčiausioji Mergele, Gvadelupès Dievo Motina, Ligoniu Sveikata, Jèzaus Motina, Pavyzdys, Vadove, Meilès Motina, Žmogiškojo Skausmo Motina, Ǐsgyvento Tikejjimo Pavyzdys, Švenčiausioji Marija, Tèvo Išrinktoji Dukte, Dievo ir Artimo Meilès Pavyzdys, Pirmoji Lotynu Amerikos Evangelizuotoja, Evangelizacijos Žvaigždè, Švenčiausioji Mergelè, Švelniausioji Motina.

\subsection{Pasaulinės ligoniụ dienos $1997 \mathrm{~m}$. vasario $11 \mathrm{~d}$. minẻjimo vieta - Fatimos (Portugalija) Marijos Rožinio Karalienès šventovė}

1997 m. vasario 11 d. iškilmès vyko Fatimos, esančios vidurio Portugalijoje, šventovejje, kuri laikoma portugalų tautos širdimi. Ši vietovẻ ypač reikšminga popiežiui Jonui Pauliui II. Dešimtujų pasikèsinimo Šv. Petro aikštèje metinių dieną Šventasis Tẻvas Jonas Paulius II nuvyko ị Fatimą ,padèkoti dieviškajai Apvaizdai, kuri savo nepaaiškinamu sprendimu lėmè, kad šis sukrečiantis ịvykis slépiningai sutaptų su pirmojo Dievo Motinos pasirodymo Cova da Iria 1917 m. gegužès 13 dieną metinėmis“ (Popiežius Jonas Paulius II, 1997, nr. 1).

1917 m. gegužès 13-ają nuošalioje Fatimos vietovẻje trims piemenèliams - Liucijai dos Santos, Pranciškui Marto ir Jacintai Marto - pasirodė Švenčiausioji Mergelè Marija. Apreiškimai kartojosi kas mènesị iki spalio 13 dienos. Viename iš pasirodymų Mergelè Marija vaikams sakè esanti Rožinio Karalienè, ragino melstis ir atgailauti. 1930 m. Katalikų Bažnyčia oficialiai patvirtino apsireiškimų tikrumą ir ne tik leido, bet ir visaip skatino pamaldumą ị Fatimos Mariją Rožinio Karalienę (Fatimos Švč. Mergelè Marija ir trečioji paslaptis, 2020). Vykstant apsireiškimams 1917 m. regètoja Liucija prašė Marijos pagydyti keletą ligonių. Marija, Rožinio Karalienè, atsakè, kad „per metus Aš kai kuriuos jų pagydysiu“ (Borelli, 2018, p. 61).

Žinioje V Pasaulinès ligonių dienos proga (Popiežius Jonas Paulius II, 1997) Jonas Paulius II pirmiausia paskelbė Fatimą minèjimo vieta (nr. 1), akcentavo Dievo Motinos Marijos svarbą vykdant ligonių sielovadą ir kvietė i̊siklausyti ị Marijos kvietimą atsiversti bei atgailauti. Šventasis Tèvas primi- 
nè, kad Motina Marija rodo ị Sūnų Jèzų Kristų (nr. 2); pats Marijos asmuo yra tikèjimo pavyzdys (nr. 3). Mariją apibūdino kaip užtarèją (nr. 5). Galiausiai mariologinejje laiško pabaigoje (nr. 6) prašè Marijos, Viešpaties Motinos ir mūsų Motinos, motiniškosios globos Pasaulinei ligonių dienai skirtoms iniciatyvoms bei ligoniams, jų artimiesiems, slaugos darbuotojams, savanoriams pagalbininkams, visiems, kurie solidarumo dvasia lydi juos jų kančiose. Marijos motiniška globa išreiškiama epitetais: Dievo Motina, Švenčiausioji Mergelè, Rožinio Karalienè, Didžioji Moteris, Užtarèja.

\subsection{Pasaulinės ligonių dienos $1998 \mathrm{~m}$. vasario $11 \mathrm{~d}$. minẻjimo vieta - Loreto (Italija) Šventụjų Namų bazilika}

1998 m. vasario 11 d. Pasaulinė ligonių diena buvo švenčiama Lorete, apie kuri popiežius sako: „Ši kukli vietovė primena momentą, kai Šventajai Dvasiai veikiant Žodis tapo kūnu Švenčiausiosios Mergelès Marijos ịsčiose, ir ragina sutelkti žvilgsnị ị İsikūnijimo slëpinį. Ne kartą kaip maldininkas lankydamasis šioje pirmutinejje tarptautinio garso šventoveje, skirtoje Švenčiausiosios Mergelès garbei ir per šimtmečius tapusioje tikra marijiškaja krikščionybės širdimi (...) visados patirdavau ypatingą artumą daugybei čia su pasitikèjimu besilankančių ligonių. Beje, kur jie galètų būti geriau priimti, jei ne namuose Tos, ị kurią Loreto litanijoje mes kreipiamès kaip ị ligoniu sveikatą ir nuliūdusiuju paguodą?" (Popiežius Jonas Paulius II, 1998, nr. 1).

Manoma, kad Loreto šventovẻ pastatyta iš Nazareto atvežus sienas namo, kuriame gyveno Švč. Mergelè Marija angelo apsilankymo ir Dievo Žodžio įsikūnijimo metu. Sienos ị Italiją atvežtos baigiantis Kryžiaus žygiams. Remiantis legenda, jas atgabenę angelai XIII a. pab. Šiandien Loretas yra viena svarbiausių piligrimystės vietų Europoje. Tad neatsitiktinai šioje šventovejje, kuri primena Dievo ịsikūnijimą Mergelèje Marijoje, popiežius Jonas Paulius II savo pontifikato laikotarpiu lankèsi net penkis kartus (Loreto Dievo Motina, 2019).

Jono Pauliaus II Žinia VI Pasaulinès ligonių dienos proga (Popiežius Jonas Paulius II, 1998), švenčiant Pasaulinę ligonių dieną Loreto Šventųjų Namų šventovejje, su Marija ypač susijusi. Tai viena ilgiausių (iš viso 10 nr.) popiežiaus žinių Pasaulinès ligonių dienos proga. Šventasis Tèvas pradeda ir 
pusę laiško skiria Marija, kuri, būdama atvira Dvasios veikimui, tampa İsikūnijusio Žodžio šventove (nr. 1-5). Pristato Mariją kaip tarnystės kenčiantiesiems pavyzdi (nr. 4), o pačius ligonius paveda Marijos užtarimui (nr. 7). Laiško pabaigoje (nr. 10) Marijai, Nuliūdusiujų Paguodai, pavedami visi fiziškai ir dvasiškai kenčiantieji, sveikatos apsaugos darbuotojai bei visi žmonès, didžiadvasiškai atsiduodantys ligonių tarnystei. Pabaigos (nr. 10) ilga malda kreipiasi i Mariją: „Loreto Mergele, ị Tave su pasitikejjimu kreipiame savo žvilgsnį. (...) Tegu Tavo globa apsaugo mus nuo pesimizmo ir mūsų laikmečio šešèliuose leidžia ịžvelgti švytinčius Viešpaties buvimo pėdsakus. Motina, Tavo švelnumui pavedame ligonių ašaras, baimes ir viltis. Tegu jų žaizdas užlieja palaimingas paguodos ir vilties balzamas! Tegu jų kentejjimai, suvienyti su Jėzaus kančia, pavirsta atpirkimo ịrankiu! Tevadovauja mums Tavo pavyzdys ir tepaverčia mūsų gyvenimą nuolatiniu Dievo garbinimu! Padaryk mus dèmesingus kitų poreikiams, j̧žvalgius, kad ateitume pagalbon kenčiančiam broliui, galinčius palydèti vienišuosius, vilties ugdytojais žmogiškųjų dramų akivaizdoje. Visuose džiaugsminguose ir liūdnuose mūsų kelio etapuose Tu motinišku švelnumu parodyk mums savo Sūnų Jėzų „o geroji, o malonioji, o mieliausioji Mergele Marija“. Amen.“ Šiame marijiniškame laiške pateikiama daugybė epitetų, skirtų Marijai: Švenčiausioji Mergelè, Vilties Moteris, Viešpaties Tarnaitè, Budraus Dèmesingumo ir Užuojautos Kenčiančiajam Ikona, Bažnyčios Motina, Nuliūdusiuju Paguoda, Loreto Mergelè, Mūsu Gyvybè, Mūsu Meilumas, Mūsu Viltis, Motina, Geroji, Malonioji, Mieliausioji Mergele Marija.

\subsection{Pasaulinès ligonių dienos $1999 \mathrm{~m}$. vasario $11 \mathrm{~d}$. minėjimo vieta - Harissos (Libanas) Dievo Motinos šventovė}

Tęsdamas nusistovejjusią tradiciją popiežius Jonas Paulius II Pasaulinei ligonių dienai 1999 m. iškilmingai švęsti parinko svarbią Artimųų Rytų Marijos šventovę - Harissos Dievo Motinos baziliką, stovinčią ant kalvos, nuo kurios veriasi vaizdas ị Beirutą. „Iš Harissos šventovès budrumu alsuojanti Švenčiausiosios Mergelès Marijos statula žvelgia ị Viduržemio jūros pakrantę, taip netoli krašto, kur vaikščiojo Jèzus, „,skelbdamas karalystès Evangeliją 
ir gydydamas žmonėse visokias ligas bei negales“ (Mt 4, 23)“ (Popiežius Jonas Paulius II, 1999, nr. 1).

Popiežius Jonas Paulius Harissos Dievo Motinos šventovejje lankèsi oficialiu vizitu Libane 1997 m. gegužès 10 d. Šioje modernioje bazilikoje aukojo šv. Mišias. 1998 m. gruodžio 8 d., minint Švenčiausios Mergelès Marijos Nekaltaji Prasidejimą, paskelbė, kad Harissoje bus švenčiama VI Pasaulinė ligonių diena. Harissos Dievo Motinos šventovè yra visų Libano krikščionių bendruomenių, priklausančių ịvairioms Bažnyčioms, ir pamaldžių musulmonų piligriminių kelionių tikslas (Popiežius Jonas Paulius II, 1999, nr. 3).

Skelbdamas Žinią VII Pasaulinès ligonių dienos proga (Popiežius Jonas Paulius II, 1999) popiežius Jonas Paulius II tęsè tradiciją švęsti Marijai dedikuotoje šventovejje (nr. 1, 3). Mariją jis pristate kaip tarnystės vargšams pavyzdị (nr. 2). Laiško pabaigoje (nr. 8) prašè Mariją globoti kenčiančiuosius: „Švenčiausioji Mergelè Marija, Harissos Dievo Motina, šią Pasaulinę ligonių dieną savo iškiliu pavyzdžiu tegu būna arti visų, kurie kenčia; tegu ji ịkvepia visus, kurie liudija krikščionių tikèjimą per tarnavimą ligoniams; tegu ji savo motiniška ranka veda kiekvieną i viso gailestingumo Tẻvo namus. Tegu ji, kuri regėjo Libano tautą draskančias kančias, per viltị, vẻl sužydẻjusią šioje šalyje, iš naujo sužadina pasauliui pasitikẻjimą gydančia meilès galia ir, kaip pražuvusius vaikus, surenka visus po savo apsiaustu.“ Šiame laiške ị Mariją kreipiamasi ịprastais vardais: Dievo Motina, Švenčiausioji Mergelè Marija, Jèzaus Motina.

\subsection{Pasaulinès ligonių dienos $2000 \mathrm{~m}$. vasario $11 \mathrm{~d}$. minèjimo vieta - Roma (Italija)}

2000-ujjų Pasaulinei ligonių dienai švęsti popiežius Jonas Paulius II konkrečios šventovès nenurodè. Žinioje, kuri skirta Pasaulinei ligonių dienai, Šventasis Tèvas tiktai paminejjo, kad ši diena bus švenčiama Romoje 2000-aisiais, Didžiojo Jubiliejaus metais (Popiežius Jonas Paulius II, 2000, nr. 1). Galima daryti prielaidą, kad Jonas Paulius II, skelbdamas Jubiliejinių metų Pasaulinę ligonių dieną, širdyje ir mintyje turèjo Romos Didžiają Švenčiausiosios Mergelès Marijos baziliką. 
Paskelbta Žinia VIII Pasaulinès ligonių dienos proga (Popiežius Jonas Paulius II, 2000) yra pati ilgiausia (iš viso 15 nr.) iš visų Jono Paulius II žinių šia proga. Nors tai pati ilgiausia žinia, joje apie Mariją mažiausiai kalbama. Popiežius tik pamini (nr. 6), kad Marijos ịsčiose ịsikūnijo Išganytojas. Ir pabaigoje (nr. 15) ligoniai ir jais besirūpinantieji pavedami Marijos globai: „Tegul mus, aktyviai dalyvaujančius savo sergančių brolių ir seserų gyvenime, lydės Mergelė Marija, kuri stovejjo prie Jėzaus kryžiaus (plg. Jn 19, 25) ir kentejo kartu su savo Sūnumi, kuri, žinodama, kas yra kančia, nuolat švelniai saugo protu ir kūnu kenčiančius nuo žmogiškosios prigimties ribotumo bei sužeidimų. Pavedu jai, Ligonių Sveikatai ir Taikos Karalienei, ligonius bei jų artimuosius, kad savo motinišku užtarimu padètų jiems kurti meilès civilizaciją“ (nr. 15). Šioje ilgoje žinioje yra tik trys Marijai skirti epitetai: Mergelè Marija, Ligoniu Sveikata, Taikos Karaliené.

\subsection{Pasaulinės ligonių dienos $2001 \mathrm{~m}$. vasario $11 \mathrm{~d}$. minėjimo vieta - Sidnėjaus (Australija) Švenčiausiosios Mergelès Marijos Bažnyčios Motinos katedra}

Pasirinkdamas Pasaulinei ligonių dienai minèti kultūriškai bei etniškai turtingą Australijos žemyną, popiežius Jonas Paulius II akcentuoja glaudų bažnytinès bendruomenès ryšị, nepaisantị atstumų ir skatinantị susitikti ịvairias kultūrines tapatybes, kurias vaisingas padarè vienatinis išlaisvinantis išganymo skelbimas. Jau pačiu šventovès pasirinkimu pabréžiamas Pasaulinės ligonių dienos marijiškasis matmuo, tikintis, kad „mylinti Motina Marija leis pajusti savo globą ne tik Australijos, bet ir viso pasaulio ligoniams, taip pat tiems, kurie ligoniams tarnauti skiria savo profesinę kompetenciją ir neretai visą savo gyvenimą“ (Popiežius Jonas Paulius II, 2001, nr. 1).

Šiandien Švenčiausiosios Marijos katedra, pastatyta centrinèje Sidnėjaus dalyje, yra vienas gražiausių ir reikšmingiausių Australijos pastatų. Nors katedros kertinis akmuo padètas $1868 \mathrm{~m}$., originalus architekto dizainas baigtas tik 2000 m. Šioje katedroje ryškejja daugybẻ dalykų: istorinis pastatas, architektūrinis stebuklas, monumentas krikščionybei, katalikiško tikejjimo įamžinimas, pagarbos Australijos katalikams išraiška. Sidnėjaus katedra, stovinti 
pirmosios Australijos katalikų koplyčios vietoje, dedikuota Švenčiausiajai Mergelei Marijai, Nekaltajai Dievo Motinai, Krikščionių pagalbai. Katedros viduje yra maždaug 40 vitražų, tarp kurių centrinis altoriaus vitražas vaizduoja Švenčiausiąją Mergelę Mariją, kurios galvą puošia didinga karūna (History of the Cathedral - Living our heritage, 2020).

Žinia IX Pasaulinès ligonių dienos proga (Popiežius Jonas Paulius II, 2001) yra viena trumpiausių (iš viso 6 nr.). Popiežius Jonas Paulius II laiško pradžioje (nr. 1) plačiai apibūdina šventimui skirtą vietą, kuri dedikuota Marijai, o laiško pabaigoje (nr. 6) ligonius paveda Marijos globai: „Patikiu jus Marijai, Bažnyčios Motinai, (...). Tegu paguodos Mergelè leidžia pajusti savo motinišką globą visiems savo kenčiantiems vaikams; tepadeda ji jums liudyti pasauliui Dievo švelnumą ir tepadaro jus gyvais savo Sūnaus atvaizdais.“ Šio laiško tiesioginiai Marijai skirti epitetai: Švenčiausioji Mergele Marija, Bažnyčios Motina, Lurdo Dievo Motina, Motina.

\subsection{Pasaulinès ligonių dienos $2002 \mathrm{~m}$. vasario $11 \mathrm{~d}$. minėjimo vieta - Vailankanni (Indija) Dievo Motinos Ligonių Sveikatos šventovè}

Dešimtą kartą Pasaulinė ligonių diena švęsta garsiame Marijos piligriminiame centre Pietų Indijoje, Vailankanni Dievo Motinos Ligonių Sveikatos šventovejje, garsèjančioje kaip „Rytų Lurdas“. Vailankanni Dievo Motinos Ligonių Sveikatos šventove ịsikūrusi Pietų Indijoje. I ją, stovinčią Bengalijos illankos pakranteje, supamą ramaus palmių giraičių peizažo, plūsta milijonai maldingų žmonių, tikinčių, kad Dievo Motina padès jiems jų varguose (Popiežius Jonas Paulius II, 2002, nr. 1).

Pamaldumas Vailankanni Dievo Motinai siejamas su XVI a. viduryje ịvykusiais trimis stebuklais bazilikos apylinkèse: Švenčiausiosios Mergelès Marijos su kūdikèliu Jèzumi apsireiškimas snaudžiančiam aviganiui, sunkiai sergančio pieno pardavėjo pasveikimas ir Portugalijos jūreivių išsigelbẻjimas per pražūtingą audrą jūroje. Iš pradžių saugiai krantą pasiekę jūreiviai pastatẻ tik kuklią koplyčią (Pattanaik, 2016). Vèliau čia pastatyta bazilika, skirta Dievo Motinai Ligonių Sveikatai. Jau šimtmečius Vailankanni traukia ne tik 
krikščionių piligrimus, bet ir kitų religijų sekejjus, ypač hinduistus, kurie Mariją, Ligonių Sveikatą, laiko rūpestinga, užjaučiančia kenčiančios žmonijos Motina. Tokio seno ir gilaus religingumo šalyje kaip Indija ši Dievo Motinai dedikuota šventovė yra skirtingų religijų susitikimo vieta ir išskirtinis religijų santarvės bei mainų pavyzdys (Popiežius Jonas Paulius II, 2002, nr. 1).

Žinia X Pasaulinès ligonių dienos proga (Popiežius Jonas Paulius II, 2002) - pati trumpiausia (tik 4 nr.) iš visų popiežiaus žinių. Jonas Paulius II pradžioje (nr. 1) apibūdina Marijai skirtą šventovę ir pabaigoje (nr. 4) meldžia jos globos kenčiantiesiems: „Meldžiu, kad Marija, Ligonių Sveikata, ir toliau globotų visus kūnu bei dvasia kenčiančius ir užtartų tuos, kurie jais rūpinasi. Tepadeda ji mums, su džiugia viltimi keliaujantiems ị saugius mūsų Tèvo namus, savo kančias vienyti su jos Sūnaus kančia.“ Šiame laiške Marija vadinama: Dievo Motina, Ligoniu Sveikata, Užjaučiančia kenčiančios žmonijos Motina.

\subsection{Pasaulinès ligonių dienos $2003 \mathrm{~m}$. vasario $11 \mathrm{~d}$. minẻjimo vieta - Vašingtono (JAV) Švenčiausiosios Mergelès Marijos Nekaltojo Prasidẻjimo bazilika}

2003 m. Pasaulinei ligonių dienai popiežius Jonas Paulius II pasirinko svarbiausią JAV katalikų nacionalinę šventovę, kviesdamas „tikinčiuosius atgręžti žvilgsnị ị Viešpaties Motiną“ (Popiežius Jonas Paulius II, 2003, nr. 1). Švenčiausiosios Mergelès Marijos Nekaltojo Prasidejimo katedra pašventinta 1865 m. Šiandien šventovejje įrengta apie 70 ịvairių tautų koplyčių, liudijančių pačios katalikų bendruomenès etninę ịvairovę JAV. Tautų koplyčios daugiausia dedikuotos Marijai. Lietuvių koplyčia dedikuota Šiluvos Švč. Mergelei Marijai (History of the Cathedral, 2020).

Popiežiaus Jono Pauliaus II Žinia XI Pasaulinès ligonių dienos proga (Popiežius Jonas Paulius II, 2003) yra viena trumpiausių (6 nr.). Jis pradžioje (nr. 1) paskelbẻ vietą, kuri susijusi su Švenčiausiąja Mergele Marija. Pabaigos maldoje (nr. 6) visus ligonius ir juos prižiūrinčiuosius pavedè Marijos globai: „Visus jus patikiu Nekaltai Pradètajai Mergelei, (...) Ligonių Sveikatai. Teišklauso ji maldavimų, kylančių iš kentẻjimų pasaulio, kad nušluostytų 
ašaras tų, kurie kenčia, kad būtų arti išgyvenančių savo ligą vienumoje ir kad savo motinišku užtarimu padètų tikintiesiems, besidarbuojantiems sveikatos apsaugos srityje, tapti ịtikimais Kristaus meilès liudytojais!“ Šiame trumpame laiške minimi šie Marijai skirti epitetai: Švenčiausioji Mergele Marija, Nekaltai Pradètoji Mergelè, Viešpaties Motina, Gvadalupès Dievo Motina, Amerikos Globeja, Ligoniu Sveikata.

\subsection{Pasaulinès ligonių dienos $2004 \mathrm{~m}$. vasario $11 \mathrm{~d}$. minẻjimo vieta - Lurdo (Prancūzija) Švenčiausiosios Mergelès Marijos Nekaltojo Prasidėjimo šventovė}

Kaip ir I Pasaulinė ligonių diena, XII vėl švenčiama Lurde, kur „1858 m. vasario 11 d. pasirodè Švenčiausioji Mergelè, kuri nuo tada tapo gausių piligriminių kelionių tikslu. Šioje kalnuotoje vietovèje Švenčiausioji Mergelè panoro parodyti savo motinišką meilę pirmiausia kenčiantiems ir sergantiems žmonèms. Nuo tada čia juntamas jos nuolatinis rūpestis“ (Popiežius Jonas Paulius II, 2004, nr. 1). Lurdo šventovė pasirinkta, nes 2004-aisiais sukako 150 metų nuo Marijos Nekaltojo Prasidèjimo dogmos paskelbimo. Skelbdamas Žinią popiežius Jonas Paulius priminè, kad 1854 m. gruodžio 8 d. popiežius Pijus IX bule „Ineffabilis Deus“ paskelbè, jog „mokymas, kad Švenčiausioji Mergelè Marija visagalio Dievo ypatinga malone bei privilegija, atsižvelgiant ị Jėzaus Kristaus, žmonijos Išganytojo, nuopelnus, buvo apsaugota nuo bet kokio gimtosios nuodėmès nešvarumo pirmuoju savo prasidèjimo momentu, yra Dievo apreikštas mokymas“. Lurde, kalbẻdama vietiniu dialektu, Marija pasakė: „Que soy era Immaculada Councepciou [Aš esu Nekaltasis Prasidejimas]“ (Popiežius Jonas Paulius II, 2004, nr. 1).

Ir ši Žinia XII Pasaulinès ligonių dienos proga (Popiežius Jonas Paulius II, 2004) yra viena trumpiausių (6 nr.). Pradžioje (nr. 1) popiežius aptarè minèjimui pasirinktą vietą. Toliau (nr. 2-3) plačiai aptarè Marijos Nekaltajj Prasidèjimą. Kalbèjo (nr. 5), kad Marija dalyvauja Jėzaus kančioje, ji yra klusnumo pavyzdys. Pabaigoje (nr. 6) visus pavedè Marijos globai: „Visus jus patikiu Švenčiausiajai Mergelei, kuri šioje Lurdo šventoveje pagerbiama Nekaltojo prasidejjimo kultu. Tegu ji padeda visiems krikščionims liudyti, 
kad vienintelis autentiškas atsakymas ị skausmą, kančią ir mirti yra Kristus, dèl mūsų miręs ir prisikèlęs mūsų Viešpats." Šio laiško tiesioginiai epitetai: Švenčiausioji Mergelè, Nekaltasis Prasidejimas, Marija iš Nazareto, Rūpestinga Motina, Žmonijos Motina.

\subsection{Pasaulinès ligonių dienos $2005 \mathrm{~m}$. vasario $11 \mathrm{~d}$. minẻjimo vieta - Jaundės (Kamerūnas) Marijos Apaštalų Karalienès šventovè}

2005 metais, praẻjus dešimčiai metų nuo III Pasaulinès ligonių dienos Dramblio Kranto Krante, vèl atsigręžta ị Afriką - Kamerūno sostinę Jaundę, esančią vidurinèje šalies dalyje. Tokiu pasirinkimu išreikštas solidarumas su Afrikos žemyno žmonėmis, kenčiančiais dèl rimtų sveikatos apsaugos problemų. Be to, taip žengtas tolesnis žingsnis igyvendinant ịsipareigojimus, Afrikos krikščionių priimtus prieš dešimtį metų vykstant III Pasaulinei ligonių dienai, būti „geraisiais samariečiais“ sunkumų turintiems broliams ir seserims (Popiežius Jonas Paulius II, 2005, nr. 1).

Jaundès miestas įsikūręs ant septynių kalvų. 1890 m. - svarbūs metai Jaundès ir viso Kamerūno Bažnyčios istorijai. Būtent tais metais pradèta krašto evangelizacija. Pirmieji misionieriai, Jono Pauliaus II teigimu, ị Kamerūną atvyko „vedini vieno troškimo: su nepažistamais kamerūniečiais dalytis tuo, ką patys buvo prièmę kaip Gerają Naujieną ir kuri jiems buvo tapusi džiaugsmo šaltiniu, pradejjusiu ryšį su Išganytoju Jėzumi Kristumi““ (cit. iš Katalikai Kamerūne ir sostinèje Jaundè. Istorija ir dabartis, 2009). Vos tik pradèję evangelizacijos misiją Kamerūne, misionieriai misijų stotyje Marienburge 1890 m. gruodžio 8 d. paaukojo šalị ir jos gyventojus Marijai, Apaštalų karalienei. Kamerūno paaukojimas Marijai nulèmè ir dabartinị sostinès katedros titulą - Marijos Apaštalų karalienès. Naujoji katedra simboliškai įamžino Kamerūno evangelizacijos pradžios ir krašto paaukojimo Marijai pirmajị šimtmeti. Didžiule šiuolaikinė Jaundès Marijos Apaštalų Karalienès, Kamerūno globejjos, šventovè pastatyta toje vietoje, kur veikẻ pirmieji Kamerūno evangelizuotojai (Katalikai Kamerūne ir sostinejje Jaundè. Istorija ir dabartis, 2009). 
Žinioje XIII Pasaulinès ligonių dienos proga (Popiežius Jonas Paulius II, 2005) mariologinè tematika minimali. Marija paminèta tik pradžioje (nr. 1), ịvardijant vietą, ir ilgoje pabaigos maldoje (nr. 7), kurioje kreipiamasi ị Mariją, šaukiantis jos, „,mūsų linksmybès priežasties“. Šiuose dviejuose laiško skyriuose aptinkami šie Marijai skirti epitetai: Švenčiausioji Mergelè Marija, Nekaltai Pradetoji Mergele, Skausmu ir Vilties Moteris, Afrikos ir Viso Pasaulio Karaliené.

Paskutinè popiežiaus Jono Pauliaus II žinia Pasaulinès ligonių dienos proga užbaigiama malda, kuri tarsi nusako visų popiežiaus žinių mintį - Marija yra pavyzdys ligoniams ir ypatinga sergančiujų globẻja: „O Marija, Nekaltai Pradètoji Mergele, skausmų ir vilties Moterie, būk palanki kiekvienam kenčiančiam žmogui ir išmelsk kiekvienam gyvenimo pilnatvę. Pažvelk motinišku žvilgsniu ypač ị tuos (...), kurie ištikti (...) ligos yra ypatingoje bejdoje. Pažvelk ị motinas, gedinčias savo vaikų; pažvelk ị senelius, kurie stokoja išteklių paremti savo našlaičius anūkus. Apkabink juos visus ir priglausk prie savo motiniškos širdies. (...) viso pasaulio Karaliene, Švenčiausioji Mergele, melski už mus!“ (Popiežius Jonas Paulius II, 2005, nr. 7).

\section{Išvados}

Šv. popiežius Jonas Paulius II vasario 11 dieną, kai Katalikų Bažnyčia liturginiame kalendoriuje mini Lurdo Švenčiausiają Mergelę Mariją, paskelbė Pasauline ligonių diena. Kartu įvedè tradiciją Pasaulinę ligonių dieną švęsti svarbioje pasirinktos šalies šventoveje, kuri dedikuota Švenčiausiajai Mergelei Marijai. Šventovių, skirtų Marijai, pasirinkimas atskleidžia: Bažnyčia užjaučia visus kenčiančiuosius fiziškai ir dvasiškai, nes pasitikint Švenčiausiosios Mergelès Marijos užtarimu kreipiamasi ị Viešpatị prašant sveikatos ligoniams, o ligoniais besirūpinantiesiems Jèzaus Motina Marija rodoma kaip tobulos Dievo ir artimo meilès pavyzdys.

Jonas Paulius II paskelbe trylika Pasaulinių ligonių dienų (1993-2005) ir parašė joms skirtus laiškus-žinias, kuriose nurodè su Švenčiausiaja Mergele Marija susijusias šventimo vietas. Iš trylikos popiežiaus Jono Pauliaus II paskelbtų Pasaulinių ligonių dienų šešios vyko Europoje (Prancūzijoje, Lenkijoje, Portugalijoje (2 kartus), Italijoje (2 kartus)), dvi - Afrikoje (Dramblio 
Kranto Krante, Kamerūne), du kartus švęsta Šiaurès Amerikoje (Meksikoje, JAV), du karus - Azijos valstybėse (Libane, Indijoje), kartą - Australijoje.

Vietos, dedikuotos Švenčiausiajai Mergelei Marijai, teikia ramybę sergantiesiems ir stiprybę jiems padedantiesiems. Ligoniai su pasitikèjimu kreipiasi ị Dievo Motiną prašydami užtarimo ir globos. Ramybė, kurią gali suteikti dieviškasis Gydytojas Jėzus Kristus Motinos Marijos užtarimu, pritraukia kenčiančiuosius ị Dievo Motinai Marijai skirtas šventoves. Kartais tai - kūno ramybè, kai Dievas savo Apvaizda išgydo ligą, vis dèlto dažniau tai būna dvasios ramybè, kai siela, persmelkta malonès vidinès šviesos, atranda jègų priimti skausmingą ligos naštą ir per bendrystę su Kristumi, kenčiančiu Dievo tarnu, paversti ją savo ir kitų išganymo įrankiu. Žvilgsnis ị prieš dvidešimt amžių Marijos ịsčiose ịsikūnijusị Išganytoją, kuris tebèra žmonijos gerovei trykštantis dieviškosios gyvybès šaltinis, padeda išgyventi ligą, iškęsti kančią. Mergelès Marijos, Sielvartingosios Motinos, dèka ligonių ir kenčiančiujų auka susiejama su velykine Kristaus atpirkimo paslaptimi, taip ịprasminant kančią.

\section{Literatūra}

Badde, P. (2008). Gvadalupe. Apsireiškimas, pakeitęs pasaulio istorija. Vilnius: Katalikų pasaulio leidiniai.

Biblija arba Šventasis Raštas. (2020). Vilnius: Lietuvos Biblijos draugija.

Borelli, A. A. (2018). Fatima: tragedijos ar vilties pranašystès? Vilnius: Krikščioniškosios kultūros institutas.

Fatimos Švč. Mergelè Marija ir trečioji paslaptis. (2020). Prieiga internete: $<\mathrm{https} / / /$ www.bernardinai.lt/2020-05-13-fatimos-svc-mergele-marija-ir-trecioji-paslaptis/> [žiūrèta 2020-10-15].

History of the Cathedral - Living our heritage. (2020). Prieiga internete: $<\mathrm{https} / /$ www.stmaryscathedral.org.au/history-art/history-of-the-cathedral/> [žiūrèta 2020-10-15].

History of the Cathedral. (2020). Prieiga internete: <https://stmaryscathedralperth. com.au/> [žiūrèta 2020-10-17].

Yamoussoukro Basilica. (2020). Prieiga internete: $<$ https://www.britannica.com/topic/Yamoussoukro-Basilica> [žiūrèta 2020-08-11].

John Paul II. (1985). Apostolic Letter Motu Proprio "Dolentium Hominum” Establishing Pontifical Commission For The Apostolate Of Health Care Workers. 
Prieiga internete: <http://www.vatican.va/content/john-paul-ii/en/motu_proprio/ documents/hf_jp-ii_motu-proprio_11021985_dolentium-hominum.html > [žiūrèta 2020-10-15].

Jonas Paulius II. (1995). Žengiant per vilties slenkstį. Vilnius: Katalikų pasaulis.

Jurkštas, S. (2014). Gvadalupès Marijos apsireiškimu istorija: ar žinome, kas iš tiesu ¡vyko? Prieiga internete: <https://www.bernardinai.1t/2014-12-12-sigitas-jurkstas-gvadalupes-marijos-apsireiskimu-istorija-ar-zinome-kas-is-tiesu-ivyko/> [žiūrèta 2020-08-11].

Katalikai Kamerūne ir sostineje Jaundè. Istorija ir dabartis. (2009). Prieiga internete: $<\mathrm{http} / / /$ www.archivioradiovaticana.va/storico/2009/03/17/katalikai kamer\%C5\%ABne ir sostin $\% C 4 \% 97 j$ je jaund $\% C 4 \% 97$ istorija ir_dabartis/lit-273468> [žiūrèta 2020-10-06]. Lileikienè, V. (2007). Prancūzijos Lurdo (Grotos) kilmè ir kelias ị Lietuvą. Tiltai. Priedas: Mokslo darbai, Nr. 36. Krikščionybès ir kultūros paralelès, p. 184-198.

Loreto Dievo Motina. (2019). Prieiga internete: <https://www.bernardinai.1t/201912-10-loreto-dievo-motina/> [žiūrèta 2020-09-15].

Makhalemele, N. T. (2020). The Theology of Sickness and Suffering According to John Paul II: A Contribution towards Pastoral Care of the Sick. Prieiga internete: <https://ost.edu/theology-sickness-suffering-according-john-paul-ii-contribution-towards-pastoral-care-sick/> [žiūrèta 2020-08-12].

Melton, J. G., Baumann, M. (2010). Religions of the World. Santa Barbara: ABC-CLIO. Message of the Holy Father Pope John Paul II for the First Annual World Day of the Sick [1993]. (1992). Prieiga internete: <https://www.vatican.va/content/johnpaul-ii/en/messages/sick/documents/hf_jp-ii_mes_21101992_world-day-of-thesick-1993.html> [žiūrèta 2020-08-06].

Message of the Holy Father Pope John Paul II for the II World Day of the Sick [1994]. (1993). Prieiga internete: <https://www.vatican.va/content/john-paul-ii/en/messages/sick/documents/hf_jp-ii_mes_08121993_world-day-of-the-sick-1994.html> [žiūrèta 2020-08-06].

Message of the Holy Father Pope John Paul II for the III World Day of the Sick [1995]. (1994). Prieiga internete: $<$ https://www.vatican.va/content/john-paul-ii/en/messages/sick/documents/hf_jp-ii_mes_21111994_world-day-of-the-sick-1995.html> [žiūrèta 2020-08-06].

Message of the Holy Father Pope John Paul II for the IV World Day of the Sick [1996]. (1995). Prieiga internete: <https://www.vatican.va/content/john-paul-ii/en/messages/sick/documents/hf_jp-ii_mes_11101995_world-day-of-the-sick-1996.html> [žiūrèta 2020-08-06].

Pastoracinė konstitucija apie Bažnyčią „Gaudium et spes“. (2001). Vatikano II Susirinkimo nutarimai. Vilnius: Aidai. 
Pattanaik, D. (2016). Virgin Mary in Vailankanni. Prieiga internete: <https://devdutt. com/articles/virgin-mary-in-vailankanni/> [žiūrèta 2020-10-15].

Popiežius Jonas Paulius II. (1994). Apaštališkasis laiškas "Tertio Millennio Adveniente” apie pasirengima 2000 metu jubiliejui. [Paskelbta 1994-11-10, žiūrèta 2020-08-11].

Popiežius Jonas Paulius II. (1997). Šventojo Tèvo laiškas [5-ajai] Pasaulinei ligoniu dienai. Prieiga internete: <https://www.baznycioszinios.1t/old/bz9702/702pop1. html> [žiūrèta 2020-08-06].

Popiežius Jonas Paulius II. (1998). Žinia rengiantis 6-ajai Pasaulinei ligonių dienai. Prieiga internete: <https://eis.katalikai.lt/vb/popieziai/jonas_paulius_ii/zinios/1997-06-29_ligoniu-diena-1998> [žiūrèta 2020-08-06].

Popiežius Jonas Paulius II. (1999). Žinia 7-osios Pasaulinès ligonių dienos proga. Prieiga internete: <https://eis.katalikai.lt/vb/popieziai/jonas_paulius_ii/zinios/1998-12-08_ligoniu-dienos-proga-1999> [žiūrèta 2020-08-06].

Popiežius Jonas Paulius II. (2000). Žinia 8-osios Pasaulinès ligoniu dienos proga. Prieiga internete: <https://eis.katalikai.lt/vb/popieziai/jonas_paulius_ii/zinios/1999-08-06_ligoniu-dienos-proga-2000> [žiūrèta 2020-08-06].

Popiežius Jonas Paulius II. (2001). Žinia 9-osios Pasaulinès ligonių dienos proga. Prieiga internete: <https://eis.katalikai.lt/vb/popieziai/jonas_paulius_ii/zinios/2000-08-22_ligoniu-dienos-proga-2001> [žiūrèta 2020-08-06].

Popiežius Jonas Paulius II. (2002). Žinia 10-osios Pasaulinès ligonių dienos proga. Bažnyčios žinios, Nr. 1 (145), p. 14-15. Prieiga internete: <https://eis.katalikai. lt/vb/popieziai/jonas_paulius_ii/zinios/2001-08-06_ligoniu-dienos-proga-2002> [žiūrèta 2020-08-06].

Popiežius Jonas Paulius II. (2003). Žinia 11-osios Pasaulinès ligoniu dienos proga. Prieiga internete: <https://eis.katalikai.lt/vb/popieziai/jonas_paulius_ii/zinios/2003-02-02_ligoniu-dienos-proga-2003> [žiūrèta 2020-08-06].

Popiežius Jonas Paulius II. (2004). Žinia 12-osios Pasaulinès ligoniu dienos proga. Prieiga internete: <https://eis.katalikai.lt/vb/popieziai/jonas_paulius_ii/zinios/2003-12-01_ligoniu-dienos-proga-2004> [žiūrèta 2020-08-06].

Popiežius Jonas Paulius II. (2005). Žinia 13-osios Pasaulinès ligoniu dienos proga. Prieiga internete: <https://eis.katalikai.lt/vb/popieziai/jonas_paulius_ii/zinios/2004-09-08_ligoniu-dienos-proga-2005> [žiūrèta 2020-08-06].

Stankevičienė, R. (2004). Čenstakavos Švč. Mergelès Marijos paveikslas: kultas ir kartotès Lietuvoje. Acta Academiae Artium Vilnensis, Nr. 35, p. 61-78.

Stumbra, S. (2019). Popiežiaus Pranciškaus laiškai Pasaulinès ligonių dienos proga. Opera theologorum Samogitarum, Nr. 6, p. 111-126.

Visuotinis Romos kalendorius. Prieiga internete: <https://lk.katalikai.lt/lkalendorius/ vrk> [žiūrèta 2020-10-06]. 


\section{MARIANISM OF THE PLACES OF COMMEMORATION OF THE WORLD DAY OF THE SICK DECLARED BY ST. POPE JOHN PAUL II}

\section{Remigijus Oželis}

Summary

The centre of Christian faith is the profession of Jesus, the son of God born of a woman. The Virgin Mary, who gave birth to Jesus, is "endowed with Grace" (Luke 1: 28). A woman in the Christian faith becomes a sign of hope leading to God. Piety to Mary the mother of God is christocentric, deeply rooted in the tripersonal mystery of God, connected to the secrets of incarnation and redemption. Mary becomes the new Eve, whom God places next to the new Adam-Christ, starting from Revelation, through the birth at Bethlehem, the wedding at Cana of Galilee to the cross of Golgotha and the supper of Pentecost. Jesus, the son of God, the reflection of God through whom all was created, merged with the Earth in human form in the womb of the Virgin Mary. The Mother of Jesus Christ the Redeemer is also the Mother of the Church, whose intercession is appealed for with confidence.

St. Pope John Paul II declared February 11, when the Catholic Church commemorates the Blessed Virgin Mary of Lourdes in the liturgical calendar, the World Day of the Sick. Also, John Paul II introduced the tradition of celebrating the World Day of the Sick every year in an important shrine dedicated to the Blessed Virgin Mary of a chosen country. The choice of such shrines dedicated to Mary reveals that the Church is attentive to all suffering physically and spiritually, that the intercession of the Blessed Virgin Mary is called upon in the prayers for health for the sick, and the Mother Mary of Jesus is shown to those caring for the sick as an example of the perfect love of God and neighbour.

John Paul II declared thirteen world days of the sick (1993-2005) and addressed them with special letters-messages, which indicated the places of commemoration associated with the Blessed Virgin Mary. Of the thirteen world days of the sick proclaimed by Pope John Paul II, six were held in 
Europe (France, Poland, Portugal (twice), Italy (twice)), two were held in African countries (Ivory Coast, Cameroon), two were celebrated in North America (Mexico, USA), two were commemorated in Asian states (Lebanon, India) and one was held in Australia.

Places dedicated to the Blessed Virgin Mary provide peace to the sick and strength to those who help them. The sick turn to the Mother of God with confidence asking for intercession and care. The peace that the divine Healer Jesus Christ can grant through the intercession of Mother Mary attracts the suffering to the shrines dedicated to the Mother of God Mary. Sometimes it is the peace of the body, when God by his providence cures the disease; but more often it is the peace of the spirit, when the soul, imbued with the inward light of grace, finds strength to accept the painful burden of the disease and, through communion with Christ, the suffering servant of God, to turn it into a tool of salvation for itself and others. The image of the Saviour incarnated in the womb of Mary twenty centuries ago, who remains the source of divine life providing for the well-being of mankind, helps to overcome disease and to endure suffering. Thanks to the Virgin Mary, the Grieving Mother, the sacrifice of the sick and suffering is combined with the Paschal mystery of Christ's atonement, thus making the suffering meaningful. 